$$
\begin{gathered}
\text { HW }-70607 \\
\text { UC-25, Metals, Ceramics } \\
\text { and Materials } \\
\text { (TID-4500, 17th Ed.) }
\end{gathered}
$$

\title{
THE IMPACT PROPERTIES OF UNALLOYED PLUTONIUMI
}

\author{
By.
}

H. R. Gardner

Plutonium Metallurgy

Reactor and Fuels Research and Development Operation

Hanford Laboratories

October, 1961

\section{HANFORD ATOMIC PRODUCTS OPERATION RICHLAND, WASHINGTON}

Work performed under Contract No. AT(45-1)-1350 between the Atomic Energy Commission and General Electric Company

Printed by/for the U. S. Atomic Energy Commission 


\section{DISCLAIMER}

This report was prepared as an account of work sponsored by an agency of the United States Government. Neither the United States Government nor any agency Thereof, nor any of their employees, makes any warranty, express or implied, or assumes any legal liability or responsibility for the accuracy, completeness, or usefulness of any information, apparatus, product, or process disclosed, or represents that its use would not infringe privately owned rights. Reference herein to any specific commercial product, process, or service by trade name, trademark, manufacturer, or otherwise does not necessarily constitute or imply its endorsement, recommendation, or favoring by the United States Government or any agency thereof. The views and opinions of authors expressed herein do not necessarily state or reflect those of the United States Government or any agency thereof. 


\section{DISCLAIMER}

Portions of this document may be illegible in electronic image products. Images are produced from the best available original document. 


\section{ABSTRACT}

The effect of temperature on the unnotched and notched Charpy impact properties of plutonium was studied in the alpha, beta, gamma, and delta phases encompassing a temperature range of -43 to $330 \mathrm{C}$.

Impact energies for unnotched specimens generally increased with increasing test temperature in the alpha and beta phases. Brittle failures were obtained in these phases. The specimen tested in the gamma phase did not fracture but bent in a $\mathrm{U}$-shape and pulled through the anvil.

Impact energies for the Charpy V-notched specimens are much lower than for the unnotched specimens at corresponding temperatures. Brittle failures were obtained in the alpha and beta phases; some ductility was evidenced in the gamma phase while the specimen tested in the delta phase did not fracture but bent in a $\mathrm{U}$-shape.

It was concluded that the beta phase is quite sensitive to both strain rate and notch effects.

Fracture appearance in the alpha and beta phase is discussed from the standpoint of grain boundary effects and microcracking. 


\section{TABLE OF CONTENTS}

\begin{tabular}{|c|c|c|c|c|c|c|c|c|}
\hline & & & & & & & & Page \\
\hline INTRODUCTION . & . & . & . & . & . & $\cdot$ & . & 4 \\
\hline SUMMARY AND CONCLUSIC & ONS & . &.. & . & . & . & . & 4 \\
\hline EXPERIMENTAL PROCEDL & JRE & . & . & . & . & . & . & 5 \\
\hline Experimental Material. & . & . & . & . & . & . & . & 5 \\
\hline Experimental Techniques & . & . & . & . & . & $\cdot$ & . & 6 \\
\hline RESULTS AND DISCUSSION & . & . & . & . & . & . & . & 6 \\
\hline Unnotched Testing & . & . & . & . & . & - & . & 6 \\
\hline Notched Testing . & . & . & . & . & . & . & . & 14 \\
\hline ACKNOW LEDGEMENT &.. & . & . & . & . & . & . & 14 \\
\hline
\end{tabular}




\section{THE IMPACT PROPERTIES OF UNALLOYED PLUTONIUM}

\section{INTRODUCTION}

The wide variation in tensile and compressive properties which exist between the alpha, beta, gamma, and delta phases of plutonium indicates that a study of the impact properties would be a pertinent supplement to the study of the mechanical properties and formability of plutonium.

In tension the alpha phase is quite brittle with elongations of less than 1 per cent. When tested at normal speeds the beta phase is unusually ductile; elongations up to 621 per cent have been obtained. However, the beta phase is quite sensitive to strain rate, elongations decrease rapidly as strain rate is increased. The gamma and delta phases are less ductile than the beta phase with the delta phase the more ductile of the two. Neither are very sensitive to strain rate.

Considering the brittle nature of alpha plutonium in tension and compression and the strain rate sensitivity of beta phase plutonium, both unnotched Charpy specimens and standard V-notched Charpy specimens were fabricated for testing. In addition, since iron in amounts greater than $500 \mathrm{ppm}$ forms a $\mathrm{Pu}-\mathrm{Pu}_{6} \mathrm{Fe}$ eutectic network which inhibits microcracking in as-cast plutonium, (1) it was decided to prepare impact specimens with both low and high iron contents.

\section{SUMMARY AND CONCLUSIONS}

Unnotched and notched plutonium impact specimens with low and high iron contents were tested at temperatures in the alpha, beta, gamma, and delta phases.

(1) Gardner, H. R. and I. B. Mann. "Mechanical Property and Formability Studies on Unalloyed Plutonium, "Second International Conference on Plutonium, Paper No. 36. Grenoble, France. April, 1960. 
For the unnotched specimens, brittle failures were obtained in both alpha and beta phases. In general, impact strength increased as test temperatures increased. Extremely ductile behavior was noted in the gamma phase. Fracture did not occur and the specimen bent in a U-shape as it was pulled through the anvil.

Fractures in the alpha phase ranged from fine to coarse as test temperature increased. In the beta phase, fine and coarse fractures were observed at the $175 \mathrm{C}$ test temperature. For both alpha and beta phases fractures are discussed from the standpoint of grain boundary effects and microcracking.

In the alpha phase, data indicated that iron additions which inhibited microcracking in plutonium resulted in a 30 per cent increase in impact strength.

It was concluded that the beta phase is very strain-rate sensitive, behaving in a brittle manner at test speeds corresponding to impact velocities.

The impact energies for the $\mathrm{V}$-notched Charpy specimens are much lower than the unnotched values at corresponding temperatures. In addition, the beta phase is shown to be quite notch-sensitive.

EXPERIMENTAL PROCEDURE

Experimental Material

Rectangular plutonium bars of square cross section were cast four at a time in vacuo in $\mathrm{MgO}$-coated graphite molds. The pouring temperature of the plutonium melt was approximately $950 \mathrm{C}$ and the molds were heated to $300 \mathrm{C}$ before pouring. The bars were removed at a mold temperature of approximately $150 \mathrm{C}$, cooled slowly to room temperature and cold treated at $-34 \mathrm{C}$ for 24 hours.

The cast bars were milled to the standard Charpy dimensions of $0.394 \times 0.394 \times 2.165$ inches. Twenty-three bars were prepared with the 
standard 45-degree Charpy V-notch. The 32 remaining bars were left unnotched. Chemical analysis and density for the groups of impact specimens tested are presented in Table I.

Experimental Techniques

For testing at elevated temperatures, the impact specimens were heated in an agitated peanut oil bath. Below room temperature an agitated bath of trichlorethylene and dry ice was used. The immersion time in both baths prior to testing was approximately 30 minutes. Transfer times from heating or cooling medium to the anvil of the impact machine were less than 5 seconds. The 0 to $60 \mathrm{ft}-\mathrm{lb}$ energy range was used for all impact testing. $\underline{\text { RESULTS AND DISCUSSION }}$

A total of 55 impact specimens, 32 unnotched and 23 with the standard Charpy $\mathrm{V}$-notch, were tested at temperatures from -43 to $330 \mathrm{C}$. The test results for both unnotched and notched specimens are presented in Table II and Figure 1.

Unnotched Testing

Unnotched specimens showed a general increase in impact energy with increasing temperature in the alpha and beta phases. Brittle failures (essentially no plastic deformation) were obtained in these phases, while extremely ductile behavior was observed in the gamma phase (Figure 2 and 3). Note that the specimen tested in the gamma phase did not fracture but bent in a U-shape as it was pulled through the anvil. These data confirm earlier observations concerning the high strain-rate sensitivity of the beta phase and the lack of strain rate effect in the gamma phase.

In the alpha phase, test temperature influenced the fracture appearance of the plutonium. As test temperature increased from -43 to $100 \mathrm{C}$ the fracture appearance changed from fine to coarse (Figures 4, 5, and 6). A complete understanding of this phenomenon cannot be derived from this study; however, it should be of advantage to discuss some of the microstructural characteristics of alpha plutonium which may have an effect on fracture appearance. 
TABLE I

CHEMICAL ANALYSIS "AND DENSITY:

\begin{tabular}{|c|c|c|c|c|c|c|c|c|c|c|c|c|}
\hline $\begin{array}{c}\text { Casting } \\
\text { Heat }\end{array}$ & $\underline{\mathrm{Al}}$ & $\underline{\mathrm{Cr}}$ & $\underline{\mathrm{Cu}}$ & $\underline{\mathrm{Fe}}$ & $\underline{\mathrm{Mg}}$ & $\underline{\mathrm{Mn}}$ & $\underline{\mathrm{Ni}}$ & $\underline{\mathrm{Si}}$ & $\underline{\mathrm{C}}$ & Total & $\begin{array}{l}\text { Density } \\
(\mathrm{g} / \mathrm{cc})\end{array}$ & \begin{tabular}{l}
\multicolumn{1}{c}{ Iron } \\
Classi- \\
ification \\
\end{tabular} \\
\hline $19-10-9$ & -- & L5 & 10 & 268 & 100 & 10 & 33 & L5 & - & 431 & 19.67 & Low \\
\hline $20-4-1 \& 2$ & 8 & 50 & 10 & L50 & 5 & 50 & 20 & 5 & 80 & 278 & 19.64 & Low \\
\hline $20-4-3 \& 4$ & 8 & 12 & 10 & 1142 & 25 & 45 & 30 & 5 & 100 & 1377 & 19.54 & High \\
\hline $21-1-2$ & 32 & 20 & 20 & 80 & 10 & 20 & 20 & L1 & -- & 203 & -- & Low \\
\hline $21-1-3$ & 20 & 50 & 10 & 1200 & 20 & 50 & 100 & 10 & -- & 1460 & 19.52 & High \\
\hline
\end{tabular}

* Reported in parts per million 
TABLE II

\section{IMPACT TEST RESULTS}

\begin{tabular}{|c|c|c|c|}
\hline \multirow{2}{*}{$\begin{array}{c}\text { Test } \\
\text { Temp., } \\
\text { C } \\
\end{array}$} & \multicolumn{3}{|c|}{$\begin{array}{l}\text { Unnotched Specimens } \\
\text { Impact Energy, ft-lb }\end{array}$} \\
\hline & Average & Range & $\begin{array}{l}\text { Number } \\
\text { Tested } \\
\end{array}$ \\
\hline-43 & 4.6 & $4.2-5.0$ & 5 \\
\hline 30 & 6.5 & $4.5-8.8$ & 9 \\
\hline 70 & 5.6 & $5.5-5.7$ & 2 \\
\hline 100 & 6.9 & 5. $1-10.0$ & 10 \\
\hline 130 & 9.9 & $8.2-12.9$ & 3 \\
\hline 175 & 7.7 & $6.5-9.0$ & 3 \\
\hline 230 & $*$ & -- & 1 \\
\hline 300 & - & -- & - \\
\hline 330 & - & -- & - \\
\hline
\end{tabular}

\begin{tabular}{ccc}
\multicolumn{3}{c}{ V-Notched Specimens } \\
Impact Energy, ft-lb \\
\hline Average & Range & $\begin{array}{c}\text { Number } \\
\text { Tested }\end{array}$ \\
\cline { 2 - 3 } 1.8 & $1.7-1.8$ & 2 \\
1.9 & -- & 2 \\
- & -- & - \\
3.1 & $2.7-3.5$ & 3 \\
1.9 & $1.8-2.0$ & 2 \\
1.8 & $1.7-2.0$ & 4 \\
11.1 & $9.9-13.5$ & 5 \\
11.0 & $9.0-13.8$ & 4 \\
$*$ & -- & 1
\end{tabular}

* Specimen bent in U-shape and did not break. 


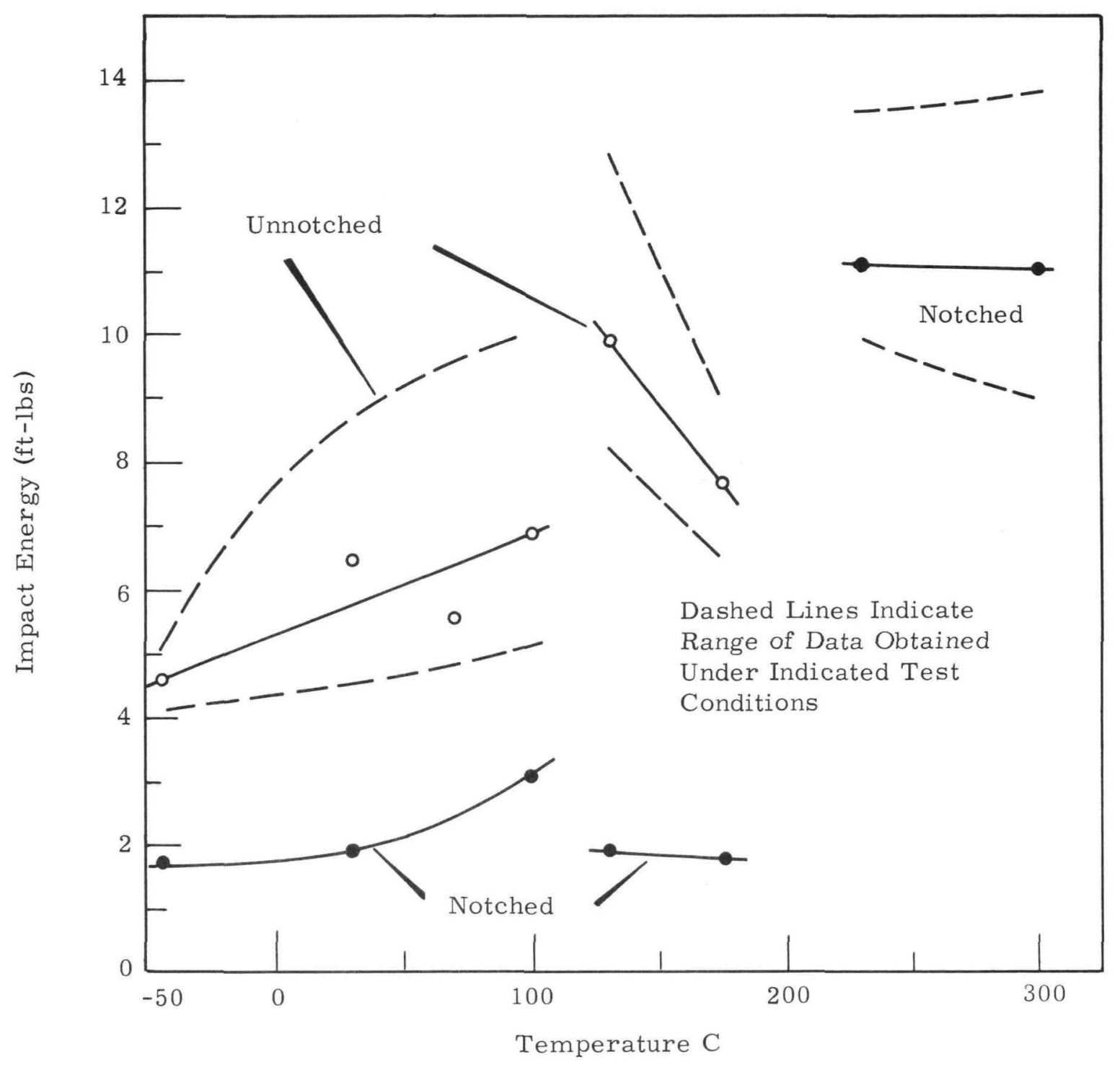

FIGURE 1

Effect of Temperature

on Unnotched and Notched Impact Properties of Plutonium 


\section{$\rightarrow$}

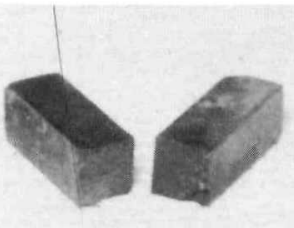

$-43 \mathrm{C}$

$100 \mathrm{C}$

FIGURE 2

Unnotched Impact Specimens

Tested at -43 and $100 \mathrm{C}$ in the Alpha Phase. 1/2X

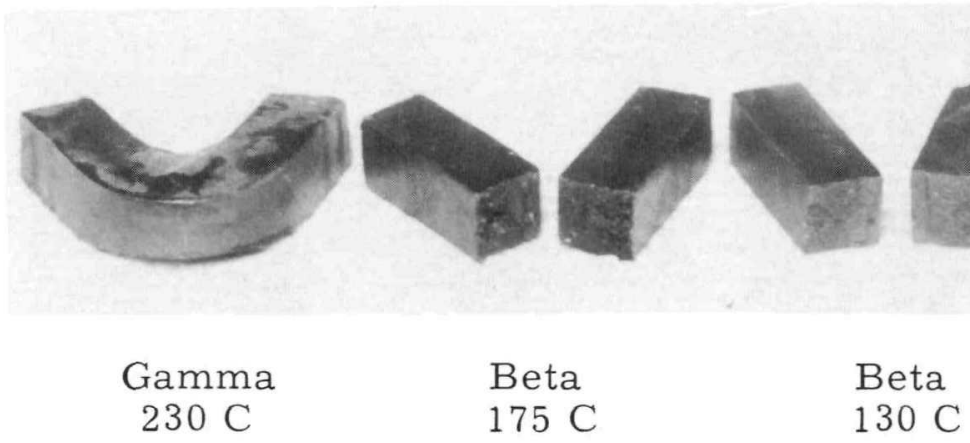

\section{FIGURE 3}

Unnotched Impact Specimens

Tested at 230,175 , and 130 C. 3/4X

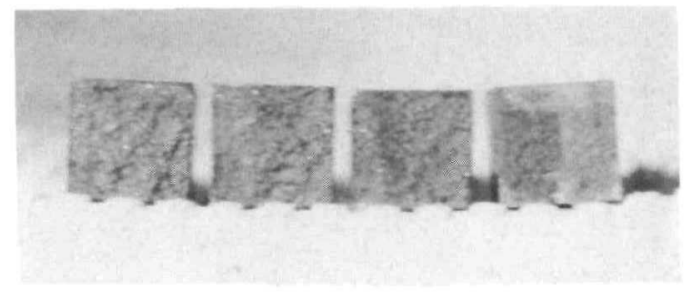

\section{$100 \mathrm{C} \quad 70 \mathrm{C} \quad 30 \mathrm{C} \quad 43 \mathrm{C}$}

\section{FIGURE 4}

Unnotched Impact Specimens Tested at 100, 70, 30 and $-43 \mathrm{C}$ in the Alpha Phase. Note Decrease in Fracture Grain Size as Test Temperature is Lowered. 1X 


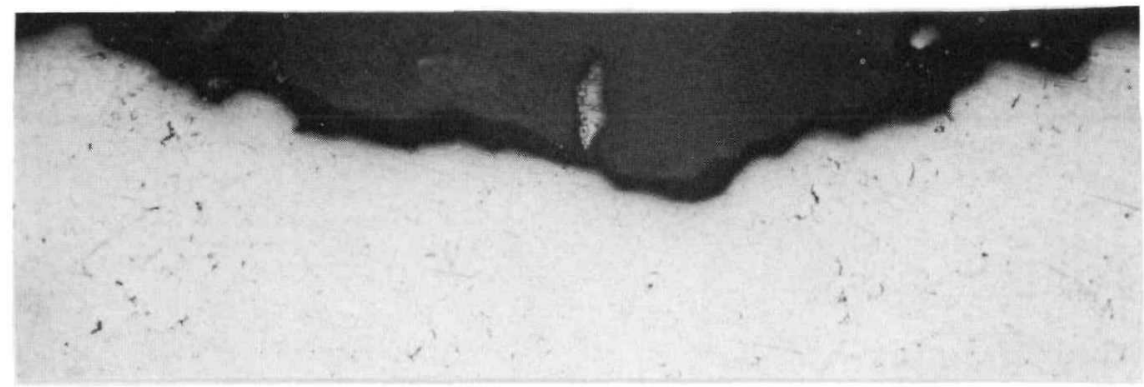

$50 \mathrm{X}$

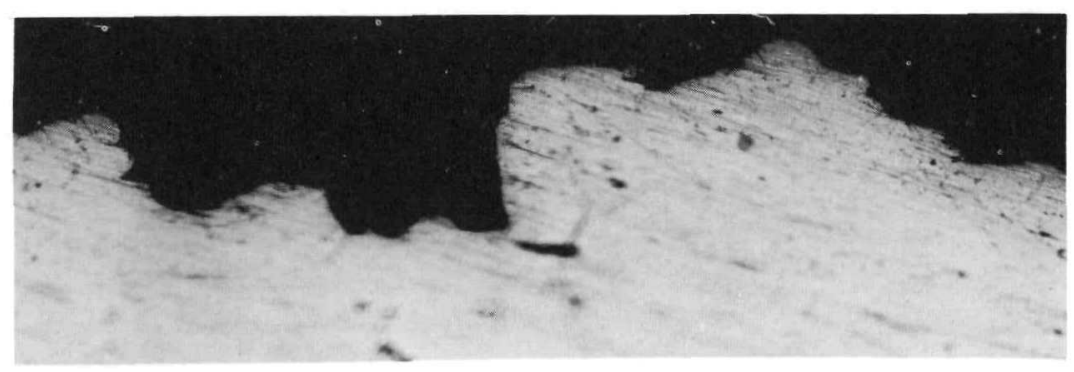

$250 \mathrm{X}$

\section{FIGURE 5}

Impact Fracture Interface at $-43 \mathrm{C}$ in Alpha Phase

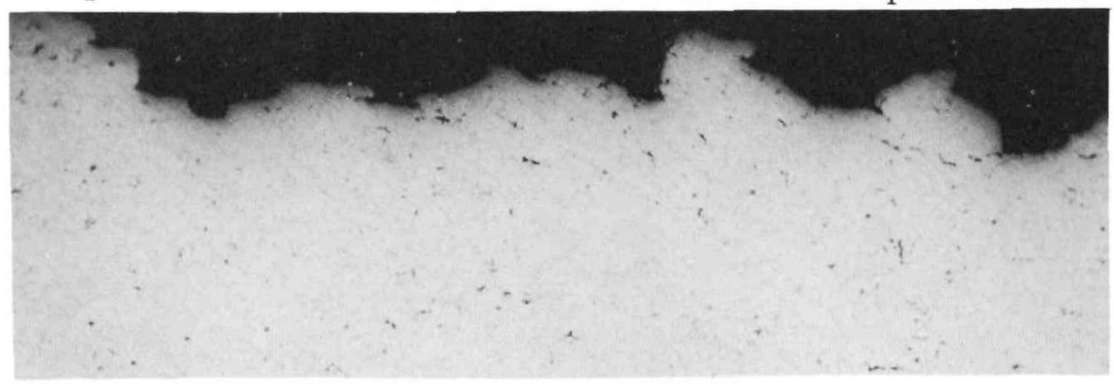

$50 X$

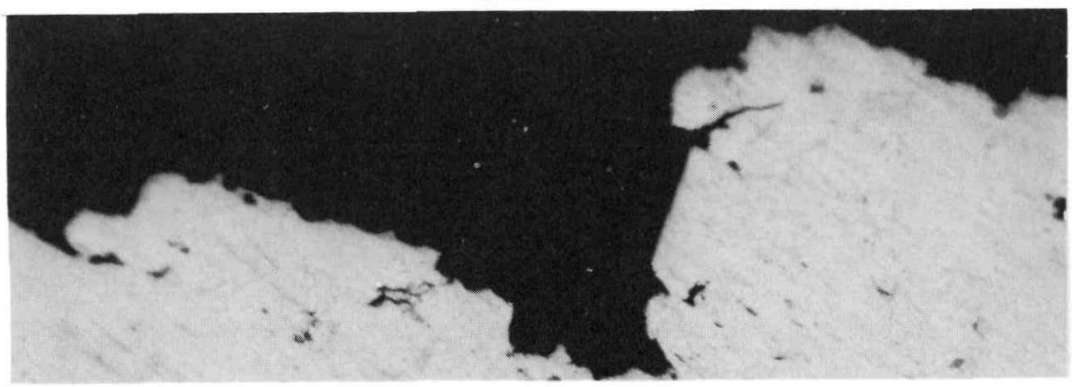

$250 \mathrm{X}$

$\underline{\text { FIGURE } 6}$

Impact Fracture Interface at $100 \mathrm{C}$ in Alpha Phase.

Note that the Fracture Interface is Coarser for the $100 \mathrm{C}$ Test Temperature 
$\mathrm{Fe}$ (1)

It has been observed in plutonium containing greater than $500 \mathrm{ppm}$ alpha grain size is approximately a factor of two finer than the size of the $\mathrm{Pu}-\mathrm{Pu}{ }_{6} \mathrm{Fe}$ eutectic network. Therefore, the microstructure of alpha plutonium contains two sets of boundaries of different sizes and probably different strengths. Considering that the boundary strengths are sensitive to temperature and each to a different degree, a graph of strengths versus temperature will show an intersection at a particular temperature. Since alpha plutonium fractures become more coarse as temperature increases, the alpha grainboundary strength must decrease at a slower rate with increasing temperature than the $\mathrm{Pu}-\mathrm{Pu}_{6} \mathrm{Fe}$ eutectic-boundary strength. Thus, at low alpha temperatures a fine, brittle intercrystalline fracture occurs at the alpha grain boundaries; while at higher temperatures the brittle intercrystalline fracture at the eutectic boundaries is more coarse. This explanation will also apply to the low impact iron plutonium specimens if it is assumed that the substantially decreased amount of eutectic present still forms a thin film of eutectic network.

Another explanation for fracture change with temperature may relate to the influence of temperature on the rate of propagation of the microcracks commonly present in alpha plutonium. The propagate a crack, it is necessary that the stress at the tip of the crack be greater than the cohesive strength of the material. Since the strength of alpha-phase plutonium increases markedly as temperature decreases, it is suggested that the rate of crack propagation decreases resulting in a finer fracture appearance at the lower test temperatures. Of course, it must be realized that interrelations affecting fracture probably exist between microcrack propagation, grain boundary, and $\mathrm{Pu}-\mathrm{Pu}_{6} \mathrm{Fe}$ eutectic network strengths.

Since the alpha phase temperature range is seldom exceeded for many applications of plutonium, sufficient impact specimens were tested at 30 and $100 \mathrm{C}$ to obtain an indication of the effect of small iron additions on the impact

(1) Ibid. 
properties of plutonium. As indicated earlier, when iron is present in plutonium in amounts greater than $500 \mathrm{ppm}$, a continuous network of $\mathrm{Pu}-\mathrm{Pu}_{6} \mathrm{Fe}$ eutectic is present which has an inhibiting effect on the formation of microcracks in cast plutonium. Thus, low-iron plutonium has microcracking of varying degrees while high-iron plutonium has little or no microcracking. In Table III the unnotched impact properties of high-and low-iron plutonium tested at 30 and $100 \mathrm{C}$ are presented.

\section{TABLE III}

UNNOTCHED IMPACT TEST DATA SEGREGATED ON BASIS OF IRON CONTENT

High Iron: $1200 \mathrm{ppm}$

Eutectic Present

Test

Temp. ,

$\mathrm{C}$

30

100 Impact Energy, ft- $1 \mathrm{~b}$

No.

$\underline{\text { Average }}$

7.5

$5.3-8.8$

7. 7

$5.7-10.0$

4

6
Low Iron: $100 \mathrm{ppm}$

Eutectic Absent Impact Energy, ft-lb

Average Range Tested

5.7
$4.5-7.8$

5. $1-6.2$

5

5.8

4

When the eutectic network is present, microcracking is essentially absent and impact energies average roughly $2 \mathrm{ft}$-lbs or 30 per cent higher than when the eutectic network is absent and microcracking is present. These data indicate that iron additions, presumably, because of their influence in inhibiting microcracks, are beneficial to the unnotched impact properties of alpha-phase plutonium.

In the beta phase, at $175 \mathrm{C}$, two extremes of fracture appearance were observed in specimens where the alpha grain sizes were essentially the same, 0.024 $\mathrm{mm}$ average grain diameter. The relatively fine fracture interface (Figure 7) may have been caused by the extensive microcracking apparent in the photomicrographs. The absence of microcracking resulted in the much coarser fracture illustrated in Figure 8. 


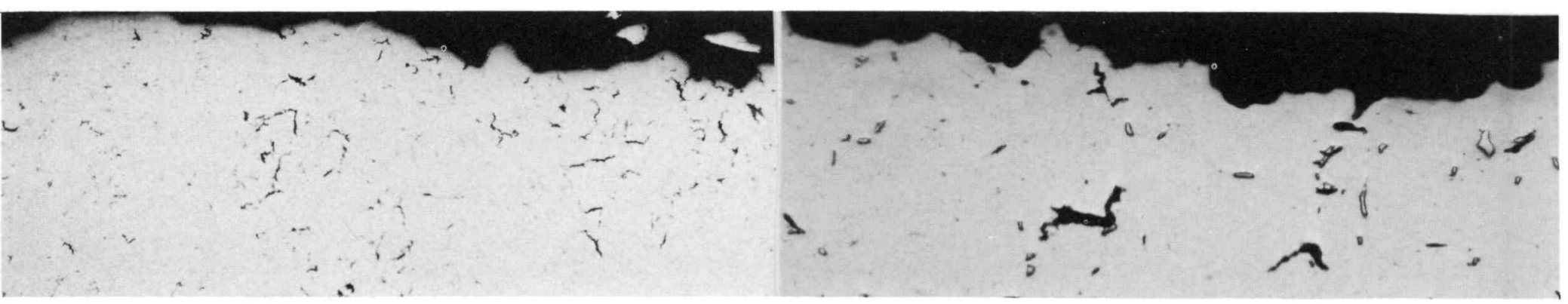

$50 \mathrm{X}$

$250 \mathrm{X}$

\section{FIGURE 7}

Fine Impact Fracture Interface at $175 \mathrm{C}$

in Beta Phase Caused by Extensive Microcracking

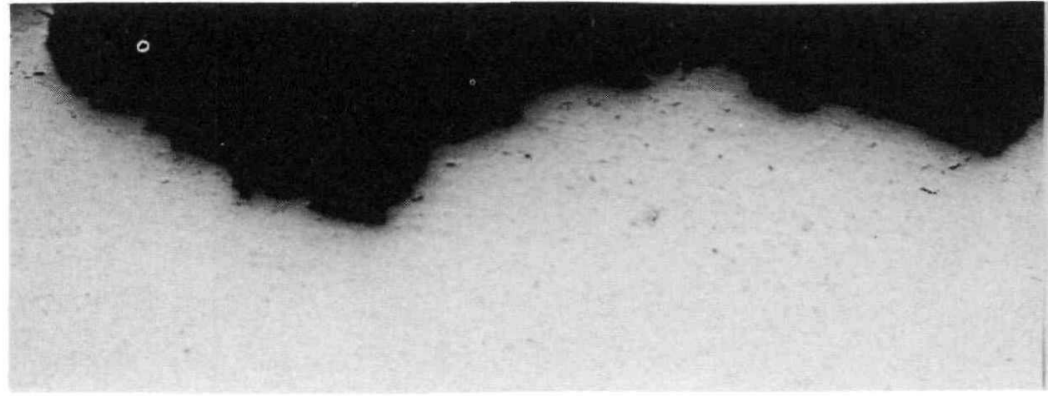

$50 \mathrm{X}$

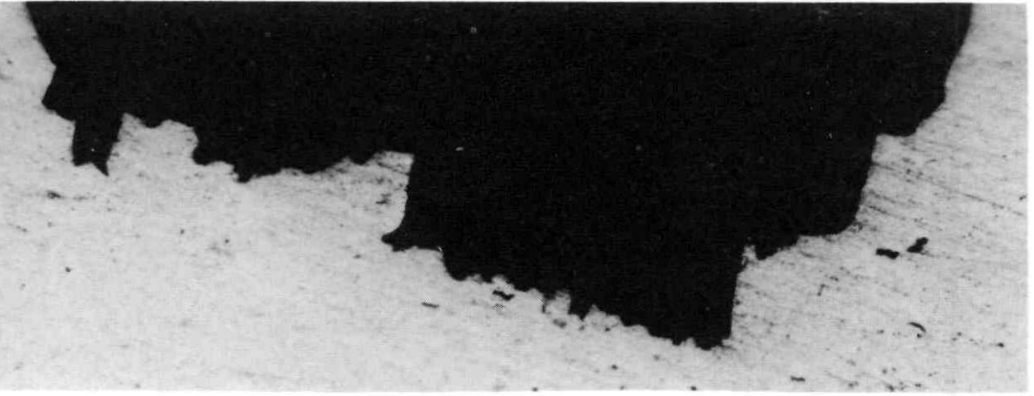

$250 \mathrm{X}$

\section{FIGURE 8}

Coarse Impact Fracture Interface at $175 \mathrm{C}$ in Beta Phase

Which Results when Microcracking is Inhibited by Iron Additions 
Notched Testing

As expected, the impact energies of the $\mathrm{V}$-notched specimens are much lower than the unnotched values at corresponding temperatures. It is interesting to note that for notched specimens the average impact energies at -43 and $30 \mathrm{C}$ in the alpha phase are equivalent to the average beta phase impact energies. However at $100 \mathrm{C}$ in the alpha phase the impact energy is almost twice as high as the beta phase value. In contrast, impact energies for unnotched beta-phase plutonium are 12 to 44 per cent higher than the impact energy of alpha phase at $100 \mathrm{C}$. These data indicate that beta-phase plutonium is very notch-sensitive for strain rates corresponding to impact velocities.

Brittle failures were obtained in the alpha and beta phases. A relatively ductile failure was observed in the gamma phase while the delta phase specimen did not fracture completely, but bent in a U-shape. This indicated extremely ductile behavior (Figures 9 and 10). As observed in the unnotched specimens tested in the alpha phase, the fracture appearance of the $\mathrm{V}$-notched specimens changed from fine to coarse when test temperature was increased from -43 to $100 \mathrm{C}$.

\section{ACKNOW LEDGEMENT}

The author is very appreciative of the excellent technical assistance provided by I. B. Mann in the experimental area of this study. Thanks are also extended to W. D. Leahy for milling the impact specimens and to J. P. Keiser for metallography. 

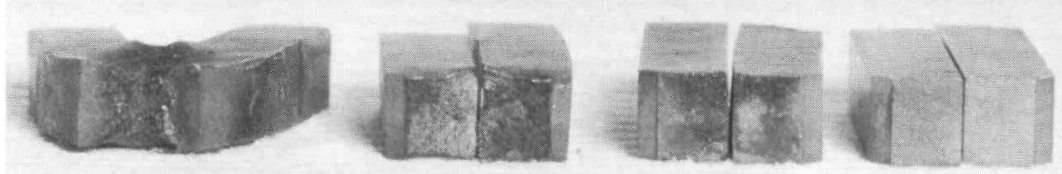

Delta
$330 \mathrm{C}$

Gamma
$230 \mathrm{C}$

Beta

Alpha

$175 \mathrm{C}$

$100 \mathrm{C}$

FIGURE 9

Charpy V-Notched Impact Specimens

Tested at $330,230,175$, and $100 \mathrm{C}$

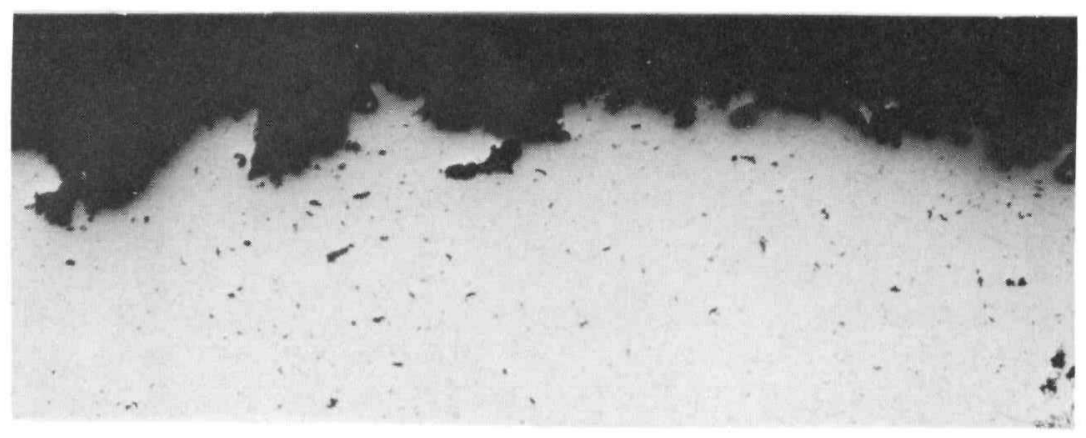

$50 \mathrm{X}$

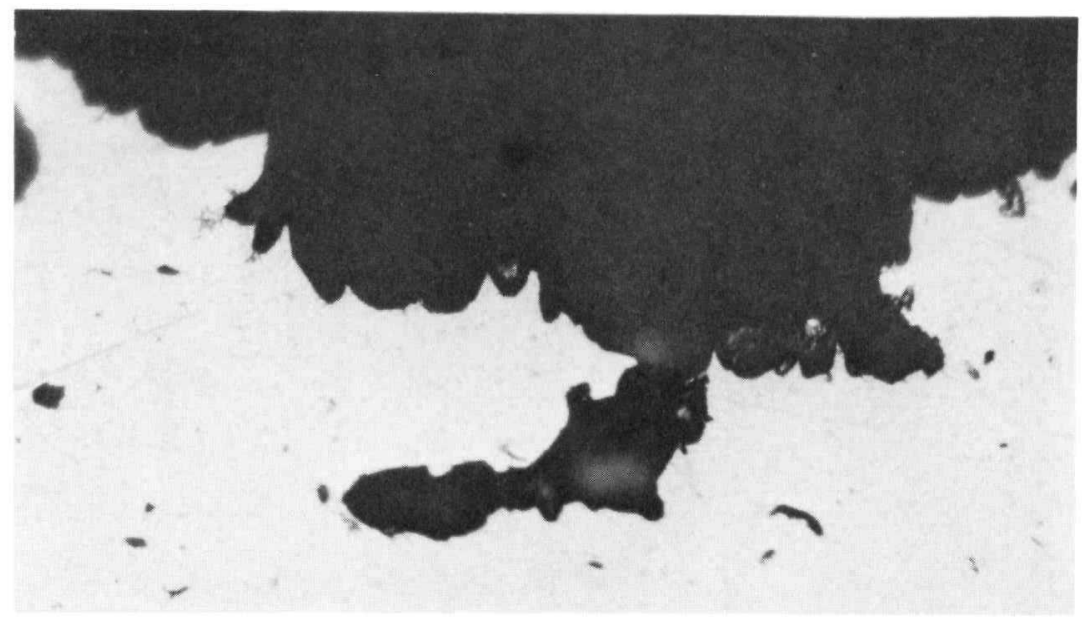

$250 \mathrm{X}$

FIGURE 10

Impact Fracture Interface at $230 \mathrm{C}$ in the Gamma Phase 


\section{INTERNAL DISTRIBUTION}

Copy Number

\begin{tabular}{|c|c|}
\hline 1 & F. W. Albaugh \\
\hline 2 & A. E. Barber \\
\hline 3 & R. E. Bardsley \\
\hline 4 & C. H. Bloomster \\
\hline 5 & L. I. Brecke \\
\hline 6 & W. G. Browne \\
\hline 7 & J. B. Burnham \\
\hline 8 & S. H. Bush \\
\hline 9 & J. J. Cadwell \\
\hline 10 & D. F. Carroll \\
\hline 11 & T. D. Chikalla \\
\hline 12 & R. E. Falkoski \\
\hline 13 & M.. D.. Freshley \\
\hline $14-39$ & $\mathrm{H}_{. .} \mathrm{R}_{.}$Gardner. \\
\hline 40 & W. J. Gartin \\
\hline 41 & W. S. Hartnett \\
\hline 42 & W. J. Hoffman \\
\hline 43 & H. H. Hopkins \\
\hline 44 & W. P. Ingalls \\
\hline 45 & Y. B. Katayama \\
\hline 46 & R. R. King, Jr. \\
\hline 47 & P. S. Kingsley \\
\hline 48 & R. K. Koler \\
\hline 49 & L. C. Lemon \\
\hline 50 & E. D. McClanahan \\
\hline 51 & J. V. McMaster \\
\hline 52 & L. G. Merker \\
\hline 53 & T. C. Nels on \\
\hline 54 & P. G. Pallmer \\
\hline 55 & H. M. Parker \\
\hline
\end{tabular}




\section{INTERNAL DISTRIBUTION (contd.)}

\section{Copy Number}

$\begin{array}{ll}56 & \text { C. S. Powers } \\ 57 & \text { M. N. Raile } \\ 58 & \text { J. H. Rector } \\ 59 & \text { W. T. Ross } \\ 60 & \text { W. Sale } \\ 61 & \text { R. E. Sharp } \\ 62-64 & \text { R. K. Sharp } \\ 65 & \text { A. E. Smith } \\ 67 & \text { R. W. Stewart } \\ 68 & \text { E. O. Swain } \\ 69 & \text { I. N. Taylor, Jr. } \\ 70 & \text { J. M. Taylor } \\ 71 & \text { I. D. Thomas } \\ 72 & \text { W. B. Weihermiller } \\ 73 & \text { O. J. Wick } \\ 74 & \text { S. H. Woodcock } \\ 75 & \text { Record Center } \\ 76 & \text { 300 File } \\ 77-79 & \text { Extra }\end{array}$

EXTERNAL DISTRIBUTION (Special)

Copy Number

80

AEC-HOO Technical Library

81

. Los Alamos Scientific Laboratory

Attn: S. E. Bronisz 


\section{EXTERNAL DISTRIBUTION}

Number of Copies

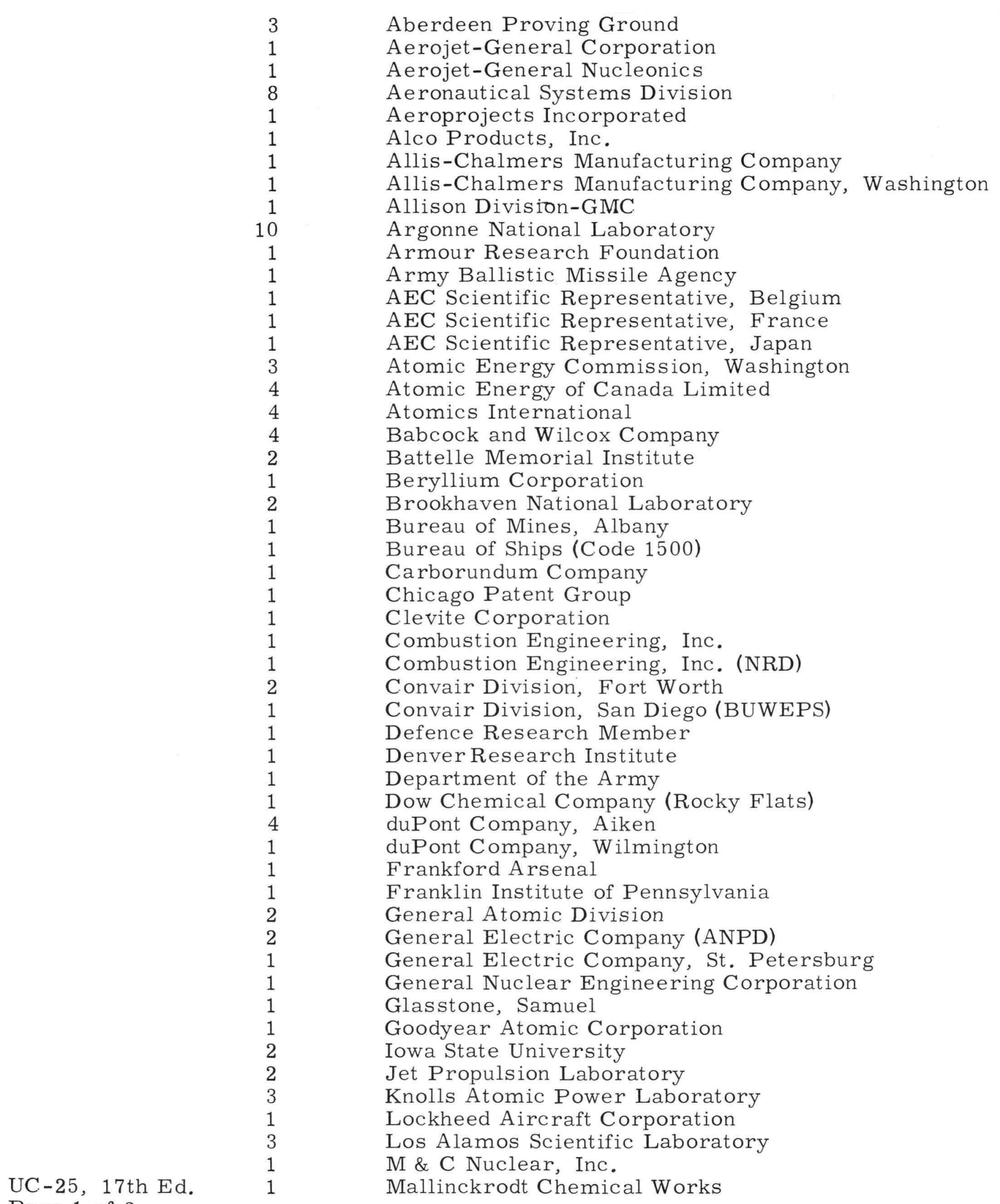


EXTERNAL DISTRIBUTION (contd.)

\section{Number of Copies}

UC-25, 17th Ed.

Maritime Administration

Martin Company

Materials Research Corporation

Mound Laboratory

NASA Lewis Research Center

National Bureau of Standards

National Bureau of Standards (Library)

National Carbon Company

National Distillers and Chemical Corporation

National Distillers and Chemical Corporation, Ashtabula

National Lead Company of Ohio

Naval Postgraduate School

Naval Research Laboratory

New Brunswick Area Office

Nuclear Materials and Equipment Corporation

Nuclear Metals, Inc.

Oak Ridge Institute of Nuclear Studies

Office of Naval Research

Office of Naval Research (Code 422)

Ordnance Materials Research Office

Ordnance Tank-Automotive Command

Patent Branch, Washington

Phillips Petroleum Company (NRTS)

Picatinny Arsenal

Power Reactor Development Company

Pratt and Whitney Aircraft Division

Purdue University

RAND Corporation

Rensselaer Polytechnic Institute

Research Analysis Corporation

Sandia Corporation, Albuquerque

Sandia Corporation, Livermore

Stevens Institute of Technology (Comstock)

Sylvania Electric Products, Inc.

Technical Research Group

Tennessee Valley Authority

Union Carbide Nuclear Company (ORGDP)

Union Carbide Nuclear Company (ORNL)

Union Carbide Nuclear Company (Paducah Plant)

United Nuclear Corporation (NDA)

United Nuclear Corporation (OMC)

U. S. Geological Survey, Denver

U. S. Geological Survey, Menlo Park

U. S. Geological Survey, Washington

U. S. Patent Office

University of California, Berkeley

University of California, Livermore

Page 2 of 3 
EXTERNAL DISTRIBUTION (contd.)

Number of Copies

1

4

1

1

325
Watertown Arsenal

Westinghouse Bettis Atomic Power Laboratory

Westinghouse Electric Corporation

Yankee Atomic Electric Company

Division of Technical Information Extension

UC-25, 17 th Ed. Page 3 of 3 